\title{
Experimental study on flexural properties of timber columns with interior notches in traditional Japanese timber structures
}

\author{
Zherui Li ${ }^{1 *}$, Hiroshi Isoda ${ }^{1}$, Akihisa Kitamori' ${ }^{2}$,Takafumi Nakagawa ${ }^{1}$, Yasuhiro Araki ${ }^{3}$ and Naohito Kawai ${ }^{4}$
}

\begin{abstract}
In this study, the columns with interior notches in traditional Japanese timber frames were selected as the research object, and static bending tests were performed to investigate the effect of interior notches on the flexural properties of columns. First, the bending behaviors of columns under three-point and four-point load configurations were compared to obtain a suitable referenced strength of a column without notches. The reduction in the load-bearing capacity of columns with different types of interior notches in traditional Japanese timber structures was determined through experimental tests and statistical analysis. The results indicated that the mean bending strength of columns with three different notch types was consistent with those without notches, the continuous timber on both sides of the notch had a beneficial effect on maintaining a higher strength and reducing the stress intensity around the notch. The fracture position and the standard deviation of the bending strength were affected not only by the notch depth, but also by the notch width on the tensile side of the column.
\end{abstract}

Keywords: Traditional timber frame, Bending strength, Interior notch, Load configuration, Wood column

\section{Introduction}

In evaluating the lateral resistance of traditional Japanese timber structures consisting of large dimensional beams, columns, and hanging walls, the performance of the main structural elements should be assessed in addition to the evaluation of shear walls. Based on quasi-static tests on a frame with deep beams and hanging mud walls [1], it was observed that the bending behavior of columns, moment resistance of the tenon-mortise joints and shear resistance of the hanging walls contributed to the lateral resistance of the entire frame. Considering that the forces generated on the joints, beams, and hanging walls are transmitted to the columns, the damage limit of the columns directly affects the load-bearing capacity of the

\footnotetext{
*Correspondence: li.zherui.72a@st.kyoto-u.ac.jp

${ }^{1}$ Research Institute for Sustainable Humanosphere, Kyoto University, Kyoto, Japan

Full list of author information is available at the end of the article
}

entire structure. In this study, the bending performance of columns in a traditional timber frame was investigated.

The load-bearing capacity of a bending member is generally estimated as the product of the effective section modulus and the characteristic bending strength [2]. The characteristic strength is normally determined through four-point (4P) bending tests $[3,4]$ considering the scale factor. In terms of traditional timber columns, the concentrated force is transferred from the beam end to the column and subjected to three-point (3P) bending. According to the evaluation of the load configuration effect based on the Weibull theory [5], the load-bearing capacity of a beam subjected to midspan $3 \mathrm{P}$ bending is approximately 1.21 that of $4 \mathrm{P}$ bending, and influenced by the stressed volume difference. Although the flexural strength under $3 \mathrm{P}$ bending is higher than that of $4 \mathrm{P}$ bending based on many experimental results $[6,7]$, the difference in the rates of increase between 3 and 4P load configurations varies, depending on the material.
Springer Open
C The Author(s) 2021. Open Access This article is licensed under a Creative Commons Attribution 4.0 International License, which permits use, sharing, adaptation, distribution and reproduction in any medium or format, as long as you give appropriate credit to the original author(s) and the source, provide a link to the Creative Commons licence, and indicate if changes were made. The images or other third party material in this article are included in the article's Creative Commons licence, unless indicated otherwise in a credit line to the material. If material is not included in the article's Creative Commons licence and your intended use is not permitted by statutory regulation or exceeds the permitted use, you will need to obtain permission directly from the copyright holder. To view a copy of this licence, visit http://creativecommons.org/licenses/by/4.0/. 
In traditional timber structures, the columns and beams are typically connected using mortise-tenon joints; consequently, interior notches are required on the columns. The abrupt change in the cross-section owing to the notch is likely to cause stress concentration and brittle failures of the bending member, significantly reducing the load-bearing capacity. Thus, the notch should be avoided or permitted based on strict restrictions in the size and location in several standards $[2,8$, 9]. The relevant estimations are also based on the analysis of the stress concentration effect at the sharp interior corner of the notch on the flexural strength. Ashby et al. [10] determined the fracture energy of a notched beam based on the crack propagation mechanism. Murphy [11, 12] simplified the large notches on a beam as slits and developed an estimation method based on stress intensity factors. A conservative crack-initiation criterion for beams with notches and slits for most softwood species is presented in the FPL wood handbook [13]. The interior notch in the above standards and studies is a general condition in which the notch penetrates the tensile side of the beam in the width direction. The height and the length ratios of the notch are mainly considered to be correlated to the flexural properties. In the case of a notch opened for the traditional tenon-mortise joint on the column, only a part of the section is cut in the width direction, and the width and depth of the notch are changeable at different positions of one joint. A combination of notches in different directions of the column may also exist (Fig. 1), which makes it challenging to analyze the flexural behavior of the column using current design methods. Shojo et al. [14] evaluated the effects of directions and the length ratio of the partial section loss on the columns and proposed a simplified bending rigidity model. The fundamental data for estimating the bending strength reduction in columns with interior notches in traditional timber frames are still limited.

The aim of this study is to investigate the load-bearing capacity of a traditional timber column for practical design, considering the possible increase caused by the load configuration effect and the possible decrease caused by the interior notches. Based on two widely used tree species and timber section sizes adopted in Japan, the flexural properties of columns without notches under $3 \mathrm{P}$ and 4P load configurations and columns with three different notch combinations in multiple directions were analyzed experimentally and statistically.

\section{Materials and methods}

Two series of experimental bending tests were conducted. In the first series, static tests under two load configurations were performed: $3 \mathrm{P}$ and $4 \mathrm{P}$ bending tests with a span-to-depth ratio of 18 . In the second series, three types of notch combinations were set at the loading point through 3P bending tests and compared with the case without notches.

\section{$3 \mathrm{P}$ and $4 \mathrm{P}$ bending tests}

The materials used in this study were Japanese cypress (Chamaecyparis obtusa) and Japanese cedar (Cryptomeria japonica), both of which are widely used as columns of traditional Japanese timber frames. During the construction of traditional buildings, the selection of column materials often depends on a visual assessment by carpenters, particularly for the materials with fewer defects around the opening. Air-dried sawn timber with drying splits and a few defects, cultivated in Yoshino, Nara Prefecture, Japan, was used for constructing the

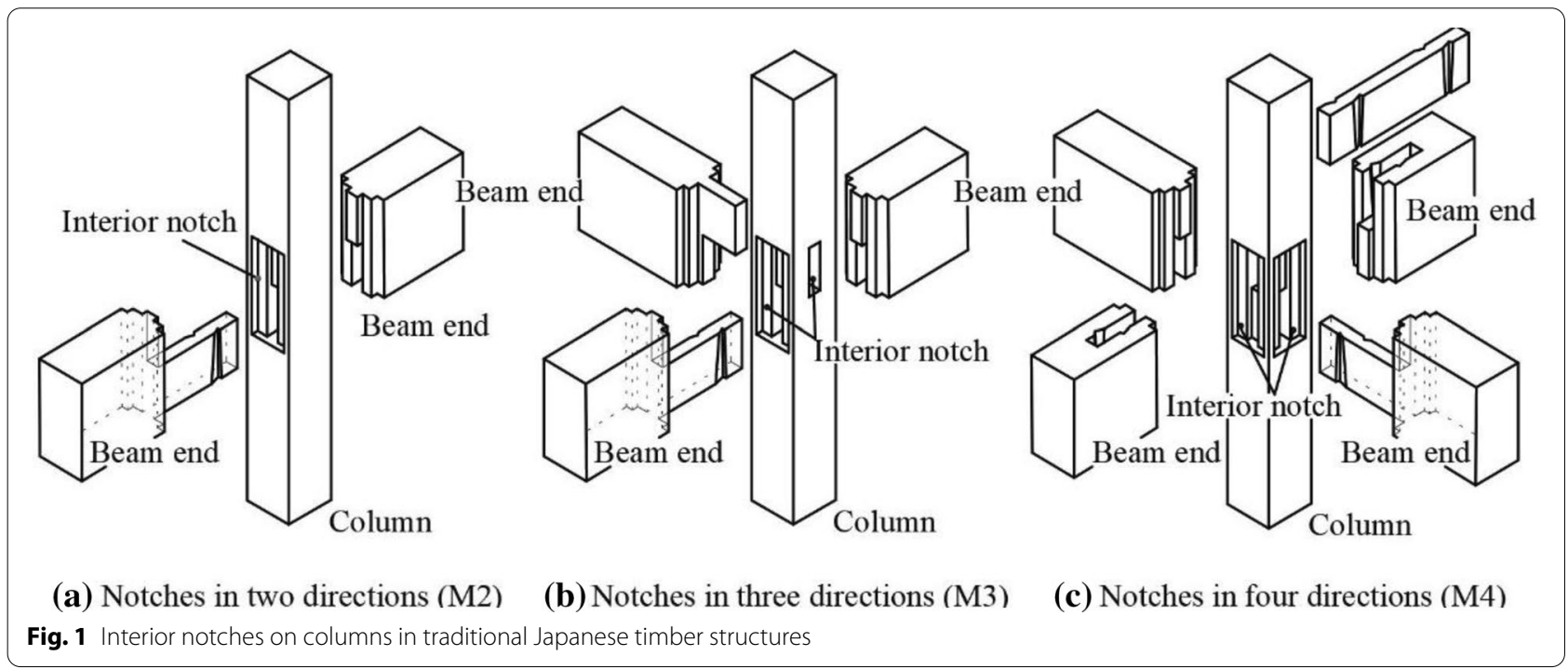


specimens. The bending specimen cross-sections were $150 \mathrm{~mm} \times 150 \mathrm{~mm}$ and $180 \mathrm{~mm} \times 180 \mathrm{~mm}$, which generally satisfy the bending requirement of independent columns. Sixteen specimens were prepared for each tree species, section size, and load configurations to satisfy the reliability of the statistical values. The dynamic modulus of elasticity in the tangential flexural vibration $\left(E_{f}\right)$ of each specimen was measured before static bending. Both the Japanese cypress and Japanese cedar specimens met the standard elastic modulus requirement of the upper class defined in the JAS standard [15].

The schematic and specifications of the simply supported specimens with a span-to-depth ratio of 18 for the bending tests are shown in Fig. 2 and Table 1, respectively. For the 3P bending test, the distance between a concentrated loading point and the support was $1 / 3 L$; for the $4 \mathrm{P}$ bending test, two equal concentrated loads with the distance of $1 / 3 L$ were placed equidistant between the supports. The crosshead speed was controlled at $8 \mathrm{~mm} /$

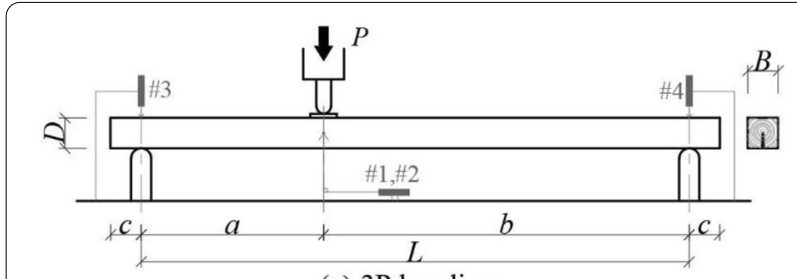

(a) $3 \mathrm{P}$ bending

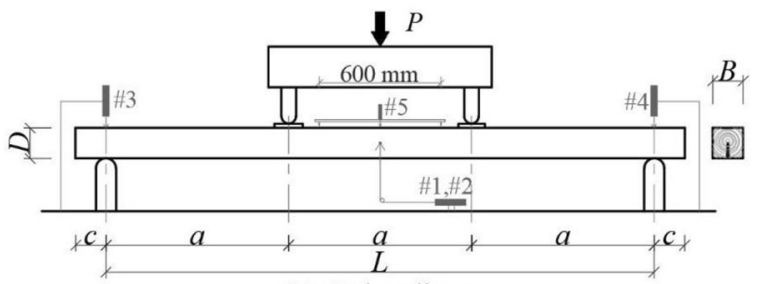

(a) $4 \mathrm{P}$ bending

Note: The displacement transducers are marked with \#

Fig. 2 Schematic of $3 \mathrm{P}$ and $4 \mathrm{P}$ bending specimens min, and the deflection was measured using displacement transducers placed at the load and support points. The names of the test specimens included details about the tree species ( $\mathrm{S}$ for Japanese cedar and $\mathrm{H}$ for Japanese cypress), section size ( 15 for a section size of $150 \mathrm{~mm}$ and 18 for a section size of $180 \mathrm{~mm}$ ), and load configuration (3P and $4 \mathrm{P}$ bending).

\section{$3 \mathrm{P}$ bending tests with and without interior notches}

The materials used for bending specimens with interior notches were homogeneous glued laminated timber composed of Japanese cypress with a strength class of E95-F315 and Japanese cedar with a strength class of E55-F225, as defined in the JAS standard [16]. In order to compare the effect of interior notch on the flexural characteristics of the columns, the $3 \mathrm{P}$ bending test was designed to be performed twice on each specimen to measure the bending performance of columns in the conditions with and without notches. The total length of the specimen was $5.3 \mathrm{~m}$, and the bending test span was $3 \mathrm{~m}$. The designed outer laminate on the tensile side was $4 \mathrm{~m}$ long without any finger joints to maintain consistency in the strength of outer laminate within the range of the stress concentration area for the two-bending tests with and without notches. A schematic and specifications of the test specimens are presented in Fig. 3 and Table 2, respectively. In addition to different tree species, the test variables included two sectional dimensions $(150 \mathrm{~mm} \times 150 \mathrm{~mm}$, and $180 \mathrm{~mm} \times 180 \mathrm{~mm})$ and three types of notches along the loading point (M2, M3, and M4). The three notches to mortise forms when the deep beams are inserted into the column from two, three, and four directions in practice. The schematic and corresponding dimensions of the different notch types are shown in Fig. 4 and Table 3, respectively. Because the width of notches $\left(e_{1}, e_{2}\right)$ in specimens with two section sizes was the same, the width loss ratio $\left(e_{2} / B\right)$ was

Table 1 Specification of $3 \mathrm{P}$ and $4 \mathrm{P}$ bending specimens

\begin{tabular}{|c|c|c|c|c|c|c|c|c|c|}
\hline Specimen & $B[\mathrm{~mm}]$ & $D[\mathrm{~mm}]$ & $L[\mathrm{~mm}]$ & $\begin{array}{l}a \\
{[\mathrm{~mm}]}\end{array}$ & $\begin{array}{l}b \\
{[\mathrm{~mm}]}\end{array}$ & $\begin{array}{l}c \\
{[\mathrm{~mm}]}\end{array}$ & $\begin{array}{l}E_{f} \\
{\left[\mathrm{kN} / \mathrm{mm}^{2}\right]}\end{array}$ & $\begin{array}{l}\text { MC } \\
{[\%]}\end{array}$ & $\begin{array}{l}\text { Number of } \\
\text { specimens }\end{array}$ \\
\hline $\mathrm{H} 15-3 \mathrm{P}$ & 150 & 150 & 2700 & 900 & 1800 & 150 & 11.33 & 14.5 & 16 \\
\hline $\mathrm{H} 15-4 \mathrm{P}$ & & & & & - & & 11.45 & 14.7 & 16 \\
\hline $\mathrm{H} 18-3 \mathrm{P}$ & 180 & 180 & 3240 & 1080 & 2160 & 380 & 11.27 & 16.5 & 16 \\
\hline $\mathrm{H} 18-4 \mathrm{P}$ & & & & & - & & 11.48 & 15 & 16 \\
\hline S15-3P & 150 & 150 & 2700 & 900 & 1800 & 150 & 9.27 & 16.8 & 16 \\
\hline S15-4P & & & & & - & & 9.39 & 16 & 16 \\
\hline S18-3P & 180 & 180 & 3240 & 1080 & 2160 & 380 & 8.61 & 22.4 & 16 \\
\hline S18-4P & & & & & - & & 8.76 & 24.3 & 16 \\
\hline
\end{tabular}




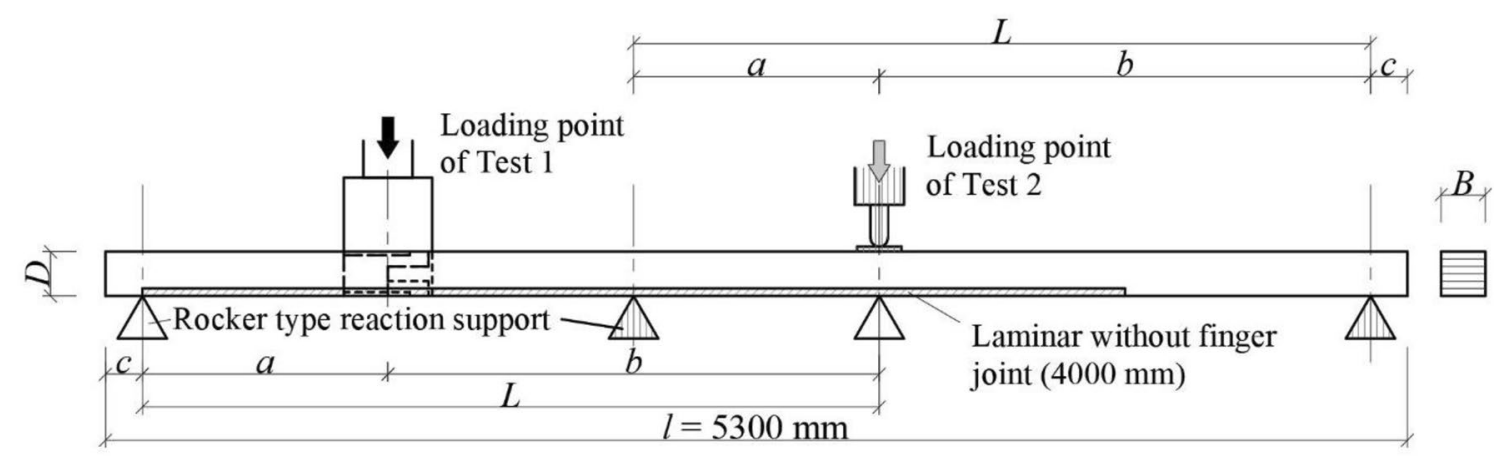

Fig. 3 Schematic of specimens with interior notches

Table 2 Specification of the specimens with interior notches

\begin{tabular}{|c|c|c|c|c|c|c|c|c|c|}
\hline Specimen & Strength class & $\begin{array}{l}B \\
{[\mathrm{~mm}]}\end{array}$ & $\begin{array}{l}D \\
{[\mathrm{~mm}]}\end{array}$ & $\begin{array}{l}L \\
{[\mathrm{~mm}]}\end{array}$ & $\begin{array}{l}a \\
{[\mathrm{~mm}]}\end{array}$ & $\begin{array}{l}b \\
{[\mathrm{~mm}]}\end{array}$ & $\begin{array}{l}c \\
{[\mathrm{~mm}]}\end{array}$ & $\begin{array}{l}\rho \\
{\left[\mathrm{g} / \mathrm{cm}^{3}\right]}\end{array}$ & $\begin{array}{l}\text { Number of } \\
\text { specimens }\end{array}$ \\
\hline HG15-M2 & \multirow[t]{6}{*}{ E95-F315 } & \multirow[t]{3}{*}{150} & \multirow[t]{3}{*}{150} & \multirow[t]{3}{*}{3000} & \multirow{3}{*}{$\begin{array}{l}1000 \\
(L \times 1 / 3)\end{array}$} & \multirow[t]{3}{*}{2000} & \multirow[t]{3}{*}{150} & 0.5 & 10 \\
\hline HG15-M3 & & & & & & & & 0.5 & 10 \\
\hline HG15-M4 & & & & & & & & 0.51 & 10 \\
\hline HG18-M2 & & \multirow[t]{3}{*}{180} & \multirow[t]{3}{*}{180} & \multirow[t]{3}{*}{3000} & \multirow{3}{*}{$\begin{array}{l}1000 \\
(L \times 1 / 3)\end{array}$} & \multirow[t]{3}{*}{2000} & \multirow[t]{3}{*}{150} & 0.49 & 10 \\
\hline HG18-M3 & & & & & & & & 0.49 & 10 \\
\hline HG18-M4 & & & & & & & & 0.52 & 10 \\
\hline SG15-M2 & \multirow[t]{6}{*}{ E55-F225 } & \multirow[t]{3}{*}{150} & \multirow[t]{3}{*}{150} & \multirow[t]{3}{*}{3000} & \multirow{3}{*}{$\begin{array}{l}1000 \\
(L \times 1 / 3)\end{array}$} & \multirow[t]{3}{*}{2000} & \multirow[t]{3}{*}{150} & 0.39 & 10 \\
\hline SG15-M3 & & & & & & & & 0.4 & 10 \\
\hline SG15-M4 & & & & & & & & 0.39 & 10 \\
\hline SG18-M2 & & \multirow[t]{3}{*}{180} & \multirow[t]{3}{*}{180} & \multirow[t]{3}{*}{3000} & \multirow{3}{*}{$\begin{array}{l}1000 \\
(L \times 1 / 3)\end{array}$} & \multirow[t]{3}{*}{2000} & \multirow[t]{3}{*}{150} & 0.41 & 10 \\
\hline SG18-M3 & & & & & & & & 0.41 & 10 \\
\hline SG18-M4 & & & & & & & & 0.4 & 10 \\
\hline
\end{tabular}

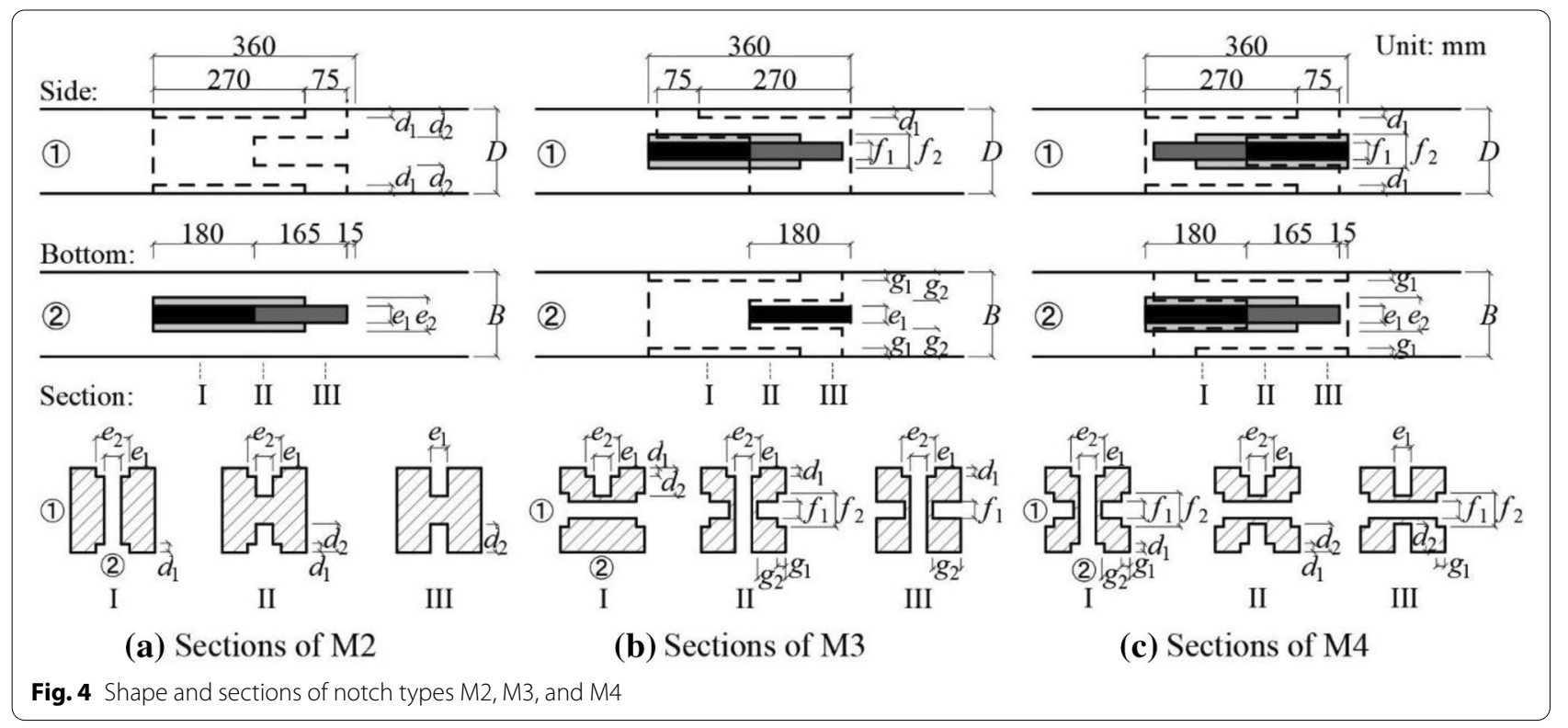


Table 3 Dimensions in the notches of different section sizes (unit: $\mathrm{mm}$ )

\begin{tabular}{llllllllll}
\hline $\boldsymbol{B} \times \boldsymbol{D}$ & $\boldsymbol{d}_{\mathbf{1}}$ & $\boldsymbol{d}_{\mathbf{2}}$ & $\boldsymbol{e}_{\mathbf{1}}$ & $\boldsymbol{e}_{\mathbf{2}}$ & $\boldsymbol{f}_{\mathbf{1}}$ & $\boldsymbol{f}_{\mathbf{2}}$ & $\boldsymbol{g}_{\mathbf{1}}$ & $\boldsymbol{g}_{\mathbf{2}}$ & $\begin{array}{l}\text { Width loss ratio } \\
\left(\boldsymbol{e}_{\mathbf{2}} / \boldsymbol{B}\right)\end{array}$ \\
\hline $150 \times 150$ & 15 & 50 & 30 & 60 & 30 & 60 & 15 & 50 & 0.40 \\
$180 \times 180$ & 15 & 60 & 30 & 60 & 30 & 60 & 15 & 60 & 0.33 \\
\hline
\end{tabular}

relatively larger in specimens with the section size of $150 \mathrm{~mm}$.

Based on the conducted frame tests [1], it was observed that the concentrated load transmitted from the deep beam led to column bending. After confirming the nominal strengths from comparative experiments of $4 \mathrm{P}$ and $3 \mathrm{P}$ bending, the column strength with interior notches at the point of the deep beam was further identified through the $3 \mathrm{P}$ bending test. The location of the deep beam in a frame varies from the middle of the column to close to the main beam, depending on the story height and the opening height as well. Considering the position of deep beams in the conducted frame tests was approximately one-third of the column, a one-third position of the concentrated force was assumed in the $3 \mathrm{P}$ bending tests. Hence, the concentrated force was applied at one-third span in Tests 1 and 2 at a crosshead speed of $6 \mathrm{~mm} / \mathrm{min}$. Instead of directly applying the load along the centerline of the notch in Test 1, the load was transferred to the specimen through a block with a tenon made of Douglas fir to simulate the connection between the beam end and the column (Fig. 5). In addition, for the specimens with notch types M3 and M4, a tenon with a cross-section of $30 \mathrm{~mm} \times 180 \mathrm{~mm}$ was inserted into the transverse opening to replicate the force transmission at the beam-column joint. Displacement transducers were placed at the load and support points to determine the deflection of the specimens. The names of test specimens included information about the tree species (SG for Japanese cedar Glulam, and HG for Japanese cypress Glulam), section size ( 15 for a section size of $150 \mathrm{~mm}$, and 18 for a section size of $180 \mathrm{~mm}$ ), and the notch type (M2, M3, and M4).

\section{Material tests}

After the 3P bending tests, tension tests were performed to determine the tensile strength parallel to the bottom laminate grain. Two clear defect-free samples were cut from the undamaged part of the continuous bottom

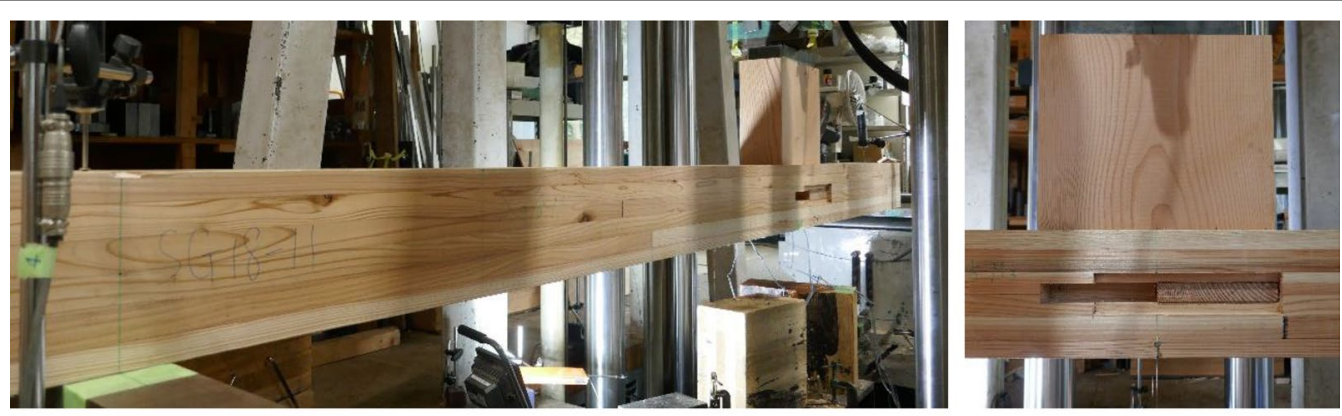

(a) Test 1: 3P bending with interior notch
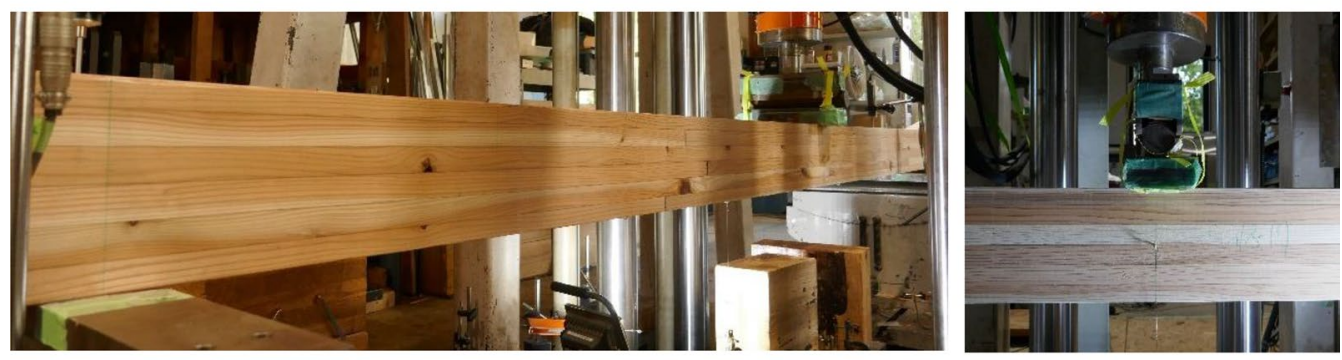

(b) Test 2: 3P bending without notches

Fig. 5 Test setup of specimens with and without interior notches 
laminate of each specimen and produced according to the JIS standard [17] (Fig. 6). The test speed was adjusted to $0.6-0.8 \mathrm{~mm} / \mathrm{min}$ to ensure that the maximum force was reached within approximately $300 \mathrm{~s}$.

\section{Results and discussion}

\section{Effect of load configuration on flexural properties}

Based on the 3P and 4P bending tests on specimens for different tree species and section sizes, the elastic modulus $\left(E_{\mathrm{b}}\right)$ and bending strength $\left(F_{\mathrm{b}}\right)$ were obtained from the applied load and deflection, using Eqs. (1)-(4). The average values of $E_{\mathrm{b}}$ and $F_{\mathrm{b}}$ of 16 specimens in each group, the corresponding standard deviations (SD), and the $5 \%$ lower tolerance limit (TL-5\%) of $F_{\mathrm{b}}$ are listed in Table 4:

$$
E_{\mathrm{b}-3 \mathrm{P}}=\frac{4 P \cdot L^{3}}{243 I \cdot \delta}\left(1+\frac{27}{20}\left(\frac{E}{G}\right)\left(\frac{D}{L}\right)^{2}\right) .
$$

In Eq. (1), $P$ is the increment in the applied load, $\delta$ is the corresponding increment in the deflection (measured using displacement transducers \#1 and \#2 in Fig. 2a), $L$ is the span between two lower supports, $D$ is the depth of the specimen, $I$ is the moment of inertia, and $\frac{E}{G}$ is assumed to be 15 .

$$
E_{\mathrm{b}-4 \mathrm{P}}=\frac{P \cdot a \cdot l^{2}}{16 I \cdot \delta^{\prime}}
$$

In Eq. (2), $P$ is the increment in the applied load, $\delta$ is the corresponding increment in the deflection (measured using displacement transducer \#5 in Fig. 2b), $a$ is the distance between the loading point and the support, and $l$ is the length of the displacement section between the load points.

$$
\begin{gathered}
F_{\mathrm{b}-3 \mathrm{P}}=\frac{2 P_{\max } \cdot L}{9 Z_{0}}, \\
F_{\mathrm{b}-4 \mathrm{P}}=\frac{P_{\max } \cdot a}{2 Z_{0}} .
\end{gathered}
$$

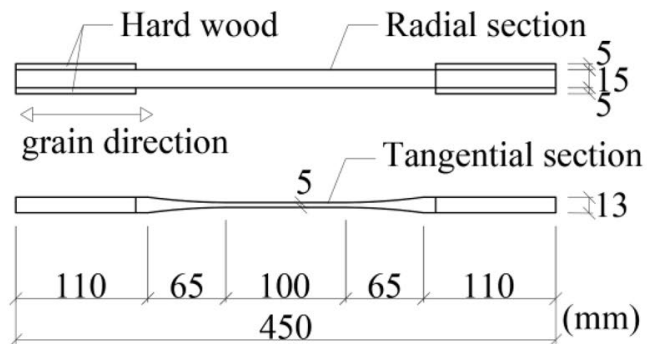

(a) Dimension of tension test specimen

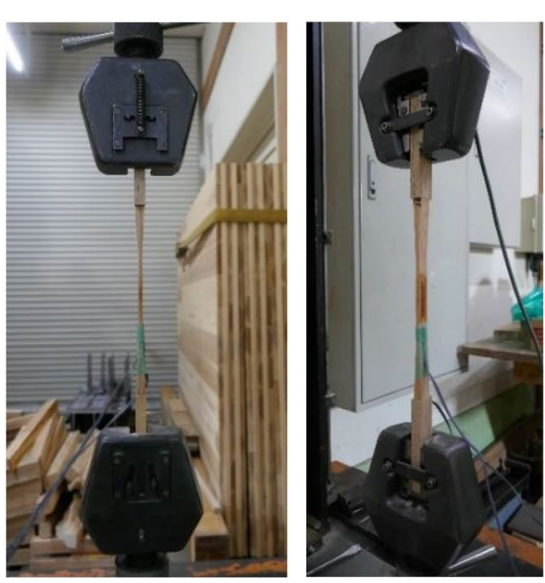

\begin{tabular}{|c|c|c|c|c|c|c|c|}
\hline Specimen & $\begin{array}{l}E_{\mathrm{b}} \\
{\left[\mathrm{kN} / \mathrm{mm}^{2}\right]}\end{array}$ & $\begin{array}{l}P_{\max } \\
{[\mathrm{kN}]}\end{array}$ & $\begin{array}{l}F_{b} \\
{\left[\mathrm{~N} / \mathrm{mm}^{2}\right]}\end{array}$ & $\begin{array}{l}F_{\mathrm{b}-3 \mathrm{P}} / F_{\mathrm{b}-4 \mathrm{P}} \\
{[\%]}\end{array}$ & SD & $\begin{array}{l}F_{\mathrm{b}}(\mathrm{TL}-5 \%) \\
{\left[\mathrm{N} / \mathrm{mm}^{2}\right]}\end{array}$ & $\begin{array}{l}\text { TL- } 5 \%_{3 \mathrm{P}} \\
/ \mathrm{TL}-5 \%_{4 \mathrm{P}} \\
{[\%]}\end{array}$ \\
\hline S15-3P & 8.66 & 44.22 & 47.17 & 107 & 8.85 & 29.72 & 103 \\
\hline S15-4P & 8.74 & 55.20 & 44.16 & & 7.75 & 28.87 & \\
\hline $\mathrm{H} 15-3 \mathrm{P}$ & 11.63 & 68.06 & 72.59 & 132 & 14.93 & 43.15 & 107 \\
\hline $\mathrm{H} 15-4 \mathrm{P}$ & 10.99 & 68.85 & 55.08 & & 7.41 & 40.46 & \\
\hline S18-3P & 7.49 & 48.07 & 35.61 & 115 & 5.48 & 24.24 & 93 \\
\hline S18-4P & 7.46 & 55.92 & 31.07 & & 2.53 & 26.07 & \\
\hline H18-3P & 10.54 & 71.80 & 53.18 & 104 & 8.74 & 35.95 & 91 \\
\hline H18-4P & 10.83 & 92.32 & 51.29 & & 5.92 & 39.62 & \\
\hline
\end{tabular}

(b) Test setup for tensile strength parallel to grain

Fig. 6 Tension test on clear samples of bottom laminate

Table 4 Flexural properties of specimens under 3P and 4P bending 
In Eqs. (3) and (4), $P_{\max }$ is the maximum force, $L$ is the span between two lower supports, $Z_{0}$ is the nominal section modulus, calculated using the width $B$ and depth $D$ of the specimen $\left(Z_{0}=\frac{B D^{2}}{6}\right)$, and $a$ is the distance between the loading point and the support.

The relationship between the static modulus $E_{\mathrm{b}}$ and dynamic modulus $E_{\mathrm{f}}$ is shown in Fig. 7a, b. A linear relationship between $E_{\mathrm{b}}$ and $E_{\mathrm{f}}$ was confirmed for specimens under $3 \mathrm{P}$ and 4P load configurations, while the dynamic value $E_{\mathrm{f}}$ tended to be slightly higher $(5 \%-10 \%)$ than $E_{\mathrm{b}}$ that determined from the static bending tests. The relation between $E_{\mathrm{b}}$ and $E_{\mathrm{f}}$ was similar to the range reported by other researchers $[18,19]$. In the static bending, the elastic modulus was calculated from the deformation at the loading point, the influence of the defects around the loading point and viscous deflection were considered as possible contributors to the lower value of $E_{\mathrm{b}}$. The relationship between the bending strengths $F_{\mathrm{b}}$ and $E_{\mathrm{f}}$ is depicted in Fig. 7c, d, and a generally linear relationship between $F_{\mathrm{b}}$ and $E_{\mathrm{f}}$ was observed. A higher coefficient of determination was obtained through 4P bending $\left(R^{2}=0.66\right)$ than 3P bending $\left(R^{2}=0.47\right)$.

In terms of the mean value of $F_{\mathrm{b}}$, the $3 \mathrm{P}$ bending strength was higher than the 4P bending strength with an average increase rate of 1.14 for both the Japanese cedar and cypress specimens of $150-\mathrm{mm}$ and $180-\mathrm{mm}$ section sizes. However, because the load-bearing capacity of specimens under 3P bending was significantly influenced by the quality of timber near the concentrated load, the standard deviation of the 3P bending strength was also higher than that of $4 \mathrm{P}$ bending strength (Fig. 8). Therefore, a comparison of the 5\% lower tolerance limit of bending strength showed that the difference between 3 and 4P bending was much decreased. Compared with other groups, the strength difference of H15-3P and $\mathrm{H} 15-4 \mathrm{P}$ specimens was larger. In addition to the

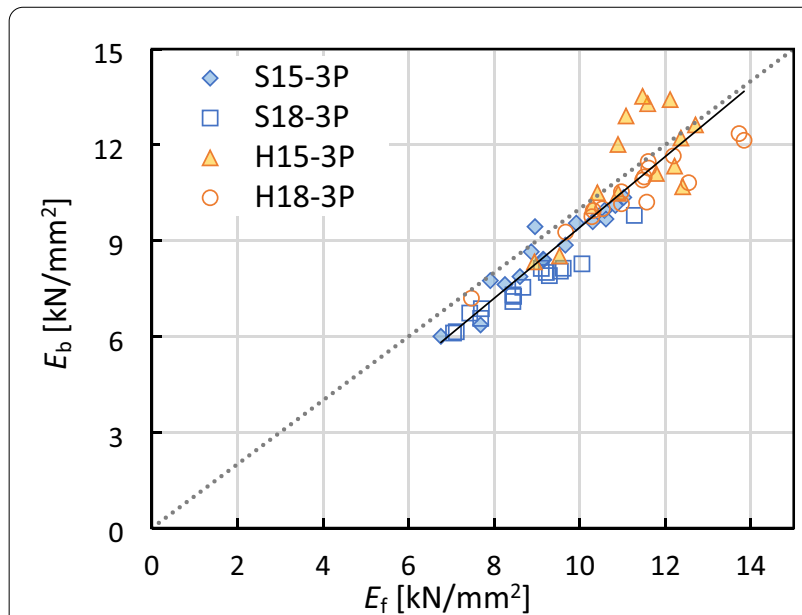

(a) $E_{\mathrm{b}}-E_{\mathrm{f}}$ relationship of $3 \mathrm{P}$ bending

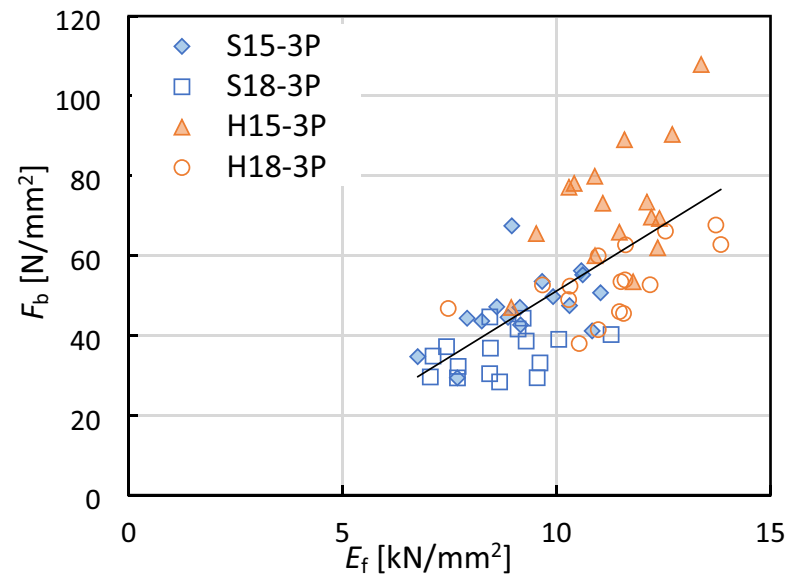

(c) $F_{\mathrm{b}}-E_{\mathrm{f}}$ relationship of $3 \mathrm{P}$ bending

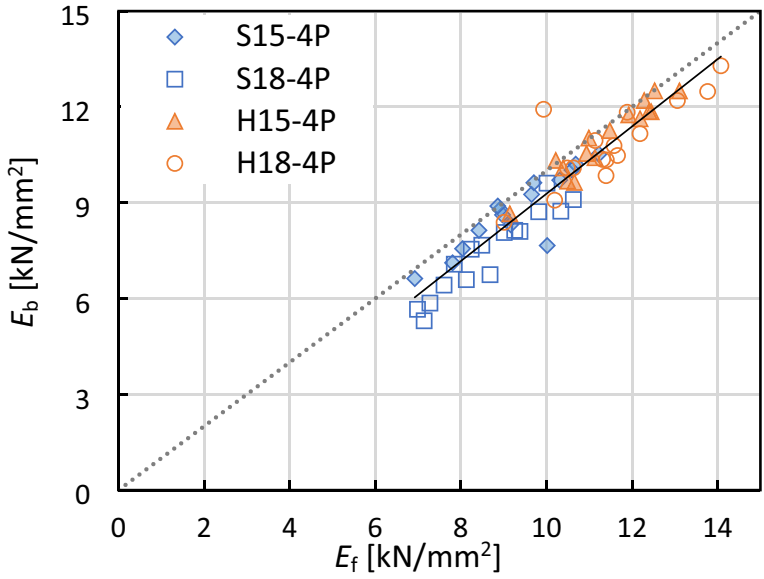

(b) $E_{\mathrm{b}}-E_{\mathrm{f}}$ relationship of $4 \mathrm{P}$ bending

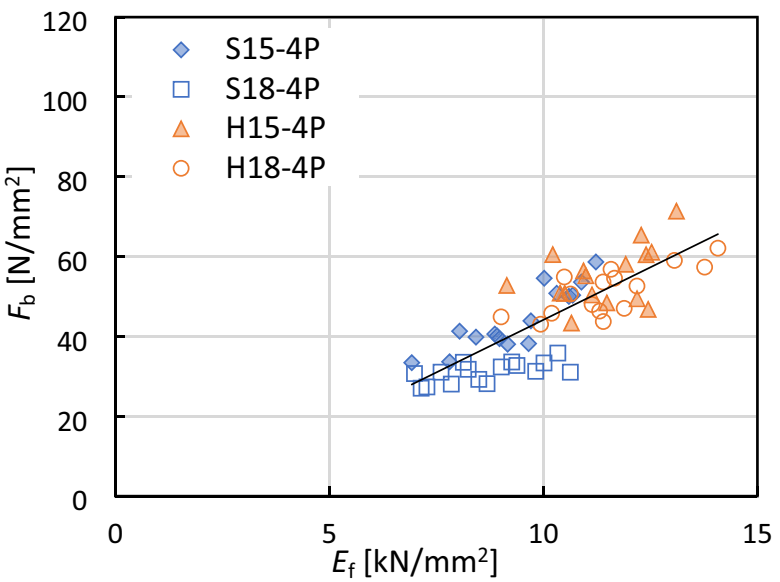

(d) $F_{\mathrm{b}}-E_{\mathrm{f}}$ relationship of $4 \mathrm{P}$ bending

Fig. 7 Relationship between $E_{\mathrm{b}}, F_{\mathrm{b}}$, and $E_{\mathrm{f}}$ of specimens under $3 \mathrm{P}$ and $4 \mathrm{P}$ bending 


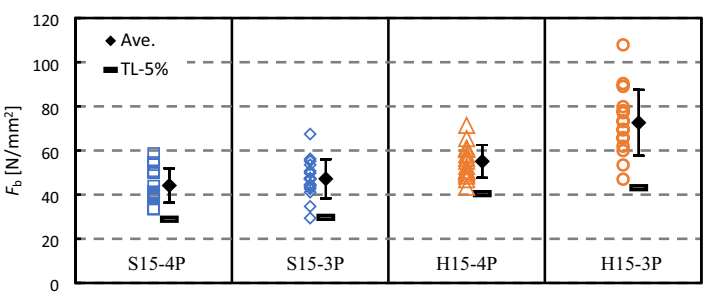

(a) $F_{\mathrm{b}}$ of $\mathrm{S} 15$ and $\mathrm{H} 15$ specimens

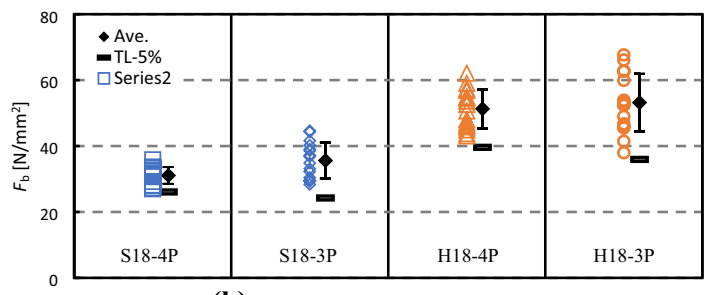

(b) $F_{\mathrm{b}}$ of $\mathrm{S} 18$ and $\mathrm{H} 18$ specimens

Fig. $8 F_{b}$ of specimens under $3 \mathrm{P}$ and $4 \mathrm{P}$ bending

influence of load configurations, one factor was that the material properties of H15-3P specimens were relatively better, which was also reflected in higher values of elastic modulus.

\section{Effect of interior notch on flexural properties}

\section{Observed damage of columns with different notch types}

In both the 3P bending test with and without interior notches, rupturing occurred on the tensile side of the specimen around the loading center and extended toward the upper laminates (Fig. 9). The irregularity of the traditional mortise shape was considered, and the failure position and the corresponding section shape (Fig. 4) of each group of 10 specimens were sorted out, as listed in Table 5. Most ruptures occurred around the sharp corners of the bottom notches, particularly for the specimens with additional shallow but wider notches on the tensile side (M2 and M4), and the failure position indicated higher correlations with the broader notch boundary, which corresponded to section shapes I and II.

The transversal opening effect on the failure mode was mainly attributed to the decrease in the net section because no significant shear failure of the specimens with notch types M3 and M4 occurred. Therefore, the failures of the specimens with notch M3 and M4 were more concentrated at the weakest net section (Shape II) than that of the specimens with notch M2. For the specimens with a section size of $180 \mathrm{~mm}$, the distribution of failure positions on different section shapes tended to be more even, due to the relatively less significant section loss of the notches.

\section{Bending properties of columns with and without interior notches}

The flexural properties of the specimens with an interior notch (Test 1 ) and without notches (Test 2), including the mean values of elastic modulus $\left(E_{\mathrm{b}}\right)$, maximum force $\left(P_{\max }\right)$, plastic ratio $\left(\delta_{\max } / \delta_{y}\right)$, bending strength $\left(F_{\mathrm{b}}\right)$, the corresponding standard deviation (SD) of $F_{\mathrm{b}}$, and $5 \%$ lower tolerance limit (TL-5\%) of $F_{\mathrm{b}}$ were determined (Table 6). The bending strengths of specimens with different notch types could also be computed using Eq. (3), and the nominal section modulus $\left(Z_{0}\right)$ was calculated based on the net section corresponding
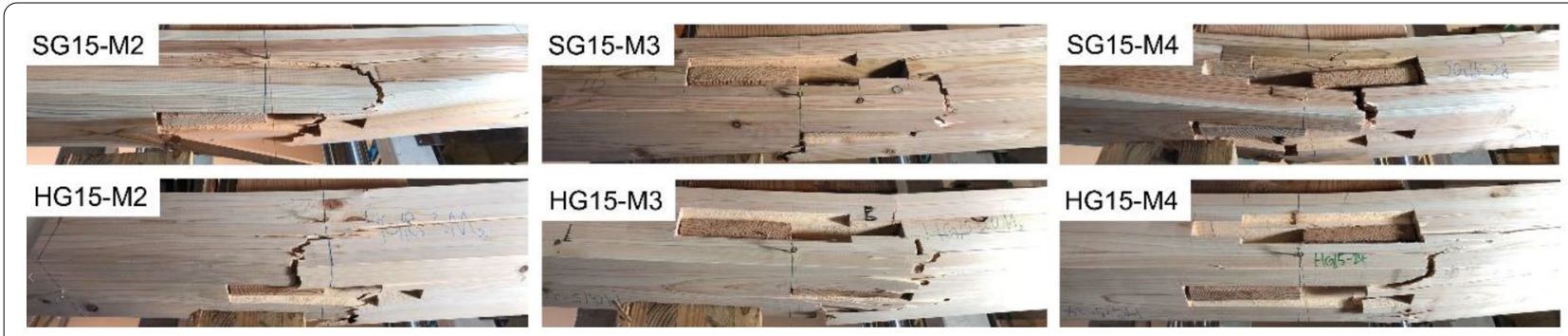

Fig.9 Typical failure of the specimens with different notch types

Table 5 Distribution of failure position in different section shapes

\begin{tabular}{|c|c|c|c|c|c|c|c|c|c|c|c|c|}
\hline \multirow[t]{2}{*}{ Section } & \multicolumn{3}{|c|}{ SG15 } & \multicolumn{3}{|c|}{ HG15 } & \multicolumn{3}{|c|}{ SG18 } & \multicolumn{3}{|c|}{ HG18 } \\
\hline & M2 & M3 & M4 & M2 & M3 & M4 & M2 & M3 & M4 & M2 & M3 & M4 \\
\hline | & $40 \%$ & $10 \%$ & $10 \%$ & $60 \%$ & $20 \%$ & $30 \%$ & $30 \%$ & $10 \%$ & $60 \%$ & $70 \%$ & $30 \%$ & $40 \%$ \\
\hline$\|$ & $50 \%$ & $80 \%$ & $60 \%$ & $30 \%$ & $70 \%$ & $70 \%$ & $40 \%$ & $70 \%$ & $40 \%$ & $30 \%$ & $40 \%$ & $50 \%$ \\
\hline III & $10 \%$ & $10 \%$ & $30 \%$ & $10 \%$ & $10 \%$ & $0 \%$ & $30 \%$ & $20 \%$ & $0 \%$ & $0 \%$ & $30 \%$ & $10 \%$ \\
\hline
\end{tabular}


Table 6 Flexural properties of specimens with and without interior notches

\begin{tabular}{|c|c|c|c|c|c|c|c|c|}
\hline Specimen & & $\begin{array}{l}E_{\mathrm{b}} \\
{\left[\mathrm{kN} / \mathrm{mm}^{2}\right]}\end{array}$ & $\begin{array}{l}P_{y} \\
{[\mathrm{kN}]}\end{array}$ & $\begin{array}{l}P_{\max } \\
{[\mathrm{kN}]}\end{array}$ & $\delta_{\max } / \delta_{y}$ & $\begin{array}{l}F_{\mathrm{b}} \\
{\left[\mathrm{N} / \mathrm{mm}^{2}\right]}\end{array}$ & SD & $\begin{array}{l}F_{\mathrm{b}}(\mathrm{TL}-5 \%) \\
{\left[\mathrm{N} / \mathrm{mm}^{2}\right]}\end{array}$ \\
\hline \multirow[t]{2}{*}{ SG15-M2 } & Test 1 & 22.26 & 6.75 & 1.27 & 25.03 & $\begin{array}{l}41.54 \\
(42.23) *\end{array}$ & $\begin{array}{l}8.74 \\
(8.32)\end{array}$ & $\begin{array}{l}23.14 \\
(24.72)\end{array}$ \\
\hline & Test 2 & 32.40 & 7.38 & 1.12 & 35.03 & 41.52 & 4.35 & 32.37 \\
\hline \multirow[t]{2}{*}{ SG15-M3 } & Test 1 & 22.92 & 6.95 & 1.10 & 24.44 & $\begin{array}{l}38.97 \\
(39.51)\end{array}$ & $\begin{array}{l}6.20 \\
(7.27)\end{array}$ & $\begin{array}{l}25.91 \\
(24.22)\end{array}$ \\
\hline & Test 2 & 28.43 & 7.10 & 1.11 & 31.06 & 36.82 & 6.01 & 24.17 \\
\hline \multirow[t]{2}{*}{ SG15-M4 } & Test 1 & 23.40 & 6.62 & 1.17 & 25.98 & $\begin{array}{l}42.45 \\
(44.90)\end{array}$ & $\begin{array}{l}4.70 \\
(6.56)\end{array}$ & $\begin{array}{l}32.57 \\
(31.09)\end{array}$ \\
\hline & Test 2 & 28.61 & 7.23 & 1.47 & 36.40 & 43.14 & 1.98 & 38.98 \\
\hline \multirow[t]{2}{*}{ HG15-M2 } & Test 1 & 37.58 & 10.66 & 1.42 & 44.46 & $\begin{array}{l}74.00 \\
(75.02)\end{array}$ & $\begin{array}{l}13.33 \\
(12.12)\end{array}$ & $\begin{array}{l}45.95 \\
(49.53)\end{array}$ \\
\hline & Test 2 & 43.23 & 12.12 & 1.93 & 63.94 & 75.78 & 5.47 & 64.28 \\
\hline \multirow[t]{2}{*}{ HG15-M3 } & Test 1 & 36.12 & 11.46 & 1.66 & 45.64 & $\begin{array}{l}72.32 \\
(73.79)\end{array}$ & $\begin{array}{l}10.96 \\
(10.36)\end{array}$ & $\begin{array}{l}49.27 \\
(51.99)\end{array}$ \\
\hline & Test 2 & 45.40 & 12.29 & 1.45 & 56.81 & 67.33 & 12.32 & 41.41 \\
\hline \multirow[t]{2}{*}{ HG15-M4 } & Test 1 & 33.00 & 10.43 & 1.50 & 40.30 & $\begin{array}{l}69.28 \\
(69.63)\end{array}$ & $\begin{array}{l}10.51 \\
(10.67)\end{array}$ & $\begin{array}{l}47.16 \\
(47.18)\end{array}$ \\
\hline & Test 2 & 44.91 & 11.91 & 1.56 & 58.64 & 69.5 & 10.49 & 47.43 \\
\hline \multirow[t]{2}{*}{ SG18-M2 } & Test 1 & 52.82 & 8.57 & 1.57 & 68.24 & $\begin{array}{l}59.46 \\
(61.33)\end{array}$ & $\begin{array}{l}6.94 \\
(6.56)\end{array}$ & $\begin{array}{l}44.86 \\
(47.54)\end{array}$ \\
\hline & Test 2 & 58.45 & 9.42 & 1.78 & 77.18 & 52.93 & 5.74 & 40.87 \\
\hline \multirow[t]{2}{*}{ SG18-M3 } & Test 1 & 54.42 & 8.95 & 1.27 & 64.07 & $\begin{array}{l}55.11 \\
(55.69)\end{array}$ & $\begin{array}{l}4.58 \\
(4.75)\end{array}$ & $\begin{array}{l}45.48 \\
(45.70)\end{array}$ \\
\hline & Test 2 & 62.19 & 9.49 & 1.58 & 77.88 & 53.42 & 5.42 & 42.02 \\
\hline \multirow[t]{2}{*}{ SG18-M4 } & Test 1 & 51.71 & 8.68 & 1.38 & 61.65 & $\begin{array}{l}55.90 \\
(56.04)\end{array}$ & $\begin{array}{l}5.48 \\
(5.44)\end{array}$ & $\begin{array}{l}44.37 \\
(44.59)\end{array}$ \\
\hline & Test 2 & 63.81 & 9.37 & 1.46 & 75.47 & 51.76 & 4.91 & 41.42 \\
\hline \multirow[t]{2}{*}{ HG18-M2 } & Test 1 & 64.97 & 10.48 & 1.26 & 73.91 & $\begin{array}{l}66.27 \\
(66.42)\end{array}$ & $\begin{array}{l}9.08 \\
(9.08)\end{array}$ & $\begin{array}{l}47.17 \\
(47.31)\end{array}$ \\
\hline & Test 2 & 77.56 & 11.40 & 1.33 & 94.31 & 64.68 & 9.14 & 45.44 \\
\hline \multirow[t]{2}{*}{ HG18-M3 } & Test 1 & 69.68 & 11.32 & 1.43 & 83.78 & $\begin{array}{l}70.74 \\
(72.83)\end{array}$ & $\begin{array}{l}6.52 \\
(7.08)\end{array}$ & $\begin{array}{l}57.02 \\
(57.94)\end{array}$ \\
\hline & Test 2 & 85.54 & 11.88 & 1.31 & 100.59 & 68.99 & 11.05 & 45.73 \\
\hline \multirow[t]{2}{*}{ HG18-M4 } & Test 1 & 67.95 & 11.32 & 1.32 & 78.54 & $\begin{array}{l}70.39 \\
(71.39)\end{array}$ & $\begin{array}{l}9.56 \\
(10.18)\end{array}$ & $\begin{array}{l}50.28 \\
(49.97)\end{array}$ \\
\hline & Test 2 & 86.82 & 12.06 & 1.23 & 98.44 & 67.52 & 10.84 & 44.72 \\
\hline
\end{tabular}

* Data in brackets were obtained from the same $Z_{0}$ based on the weakest net section of each notch type (Fig. 10)

to the failure position of each specimen. The ratio of $Z_{0}$ between the entire section and the net section of each notch type is listed in Table 7 . Considering the convenience in practical design, the brackets in Table 6 also listed the bending strength obtained from the same $Z_{0}$ based on the weakest net section of each notch type (Fig. 10). The difference between bending strengths

Table 7 Ratio of $Z_{0}$ between entire section and net section of different notch types

\begin{tabular}{|c|c|c|c|c|c|c|}
\hline \multirow{2}{*}{$\begin{array}{l}\text { Section } \\
\text { shape }\end{array}$} & \multicolumn{2}{|l|}{$Z_{0-\mathrm{M} 2} / Z_{0}$} & \multicolumn{2}{|l|}{$Z_{0-\mathrm{M}} / Z_{0}$} & \multicolumn{2}{|l|}{$Z_{0-M 4} / Z_{0}$} \\
\hline & $150 \times 150 \mathrm{~mm}$ & $180 \times 180 \mathrm{~mm}$ & $150 \times 150 \mathrm{~mm}$ & $180 \times 180 \mathrm{~mm}$ & $150 \times 150 \mathrm{~mm}$ & $180 \times 180 \mathrm{~mm}$ \\
\hline | & 0.70 & 0.76 & 0.82 & 0.86 & 0.69 & 0.75 \\
\hline$\|$ & 0.71 & 0.77 & 0.73 & 0.79 & 0.69 & 0.76 \\
\hline III & 0.81 & 0.84 & 0.74 & 0.79 & 0.79 & 0.83 \\
\hline
\end{tabular}




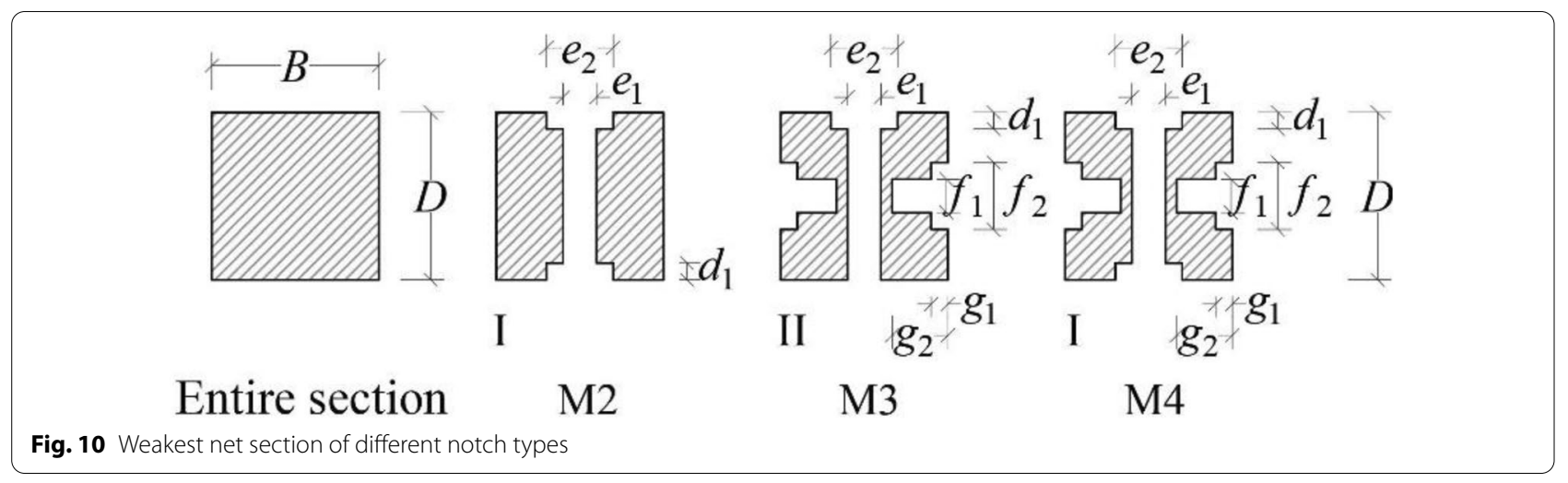

calculated from the weakest net section and that from the net section of failure positions was insignificant.

It was found that the bending strength of specimens with a notch on average obtained using the nominal section modulus of the net section was generally consistent with those of specimens without notches. Overall, the standard deviation of the bending strength of specimens produced with Japanese cypress was higher than that of Japanese cedar. From the standard deviation of bending strength, the overall tendency was not clear. However, compared with the specimens with the notch type M3, the value of SD in Test 1 with a notch was higher than that in Test 2 without notches for specimens with notch types M2 and M4. The possible influence was reflected in a larger section loss on the tensile side caused by the notch shape. In addition, this difference between SD in Test 1 and Test 2 in specimens of the $150 \mathrm{~mm}$ section size was more obvious than that of $180 \mathrm{~mm}$ for the same notch type, which was influenced by a higher percentage of width loss ratio on the tensile side of the specimens. Based on the comparison between specimens with notch types M2 and M4, the effect of the transverse opening and notch on the bending strength was insignificant. When the transverse opening was filled with a tenon, the transmission of the applied load from the compressive side to the tensile side was facilitated, reducing the stress concentration at the opening.

Because the bending performance of the Glulam specimens was significantly influenced by the tensile strength of the outer laminate on tensile side, the tensile properties of the outer laminate were obtained through the material tests (Table 8). Both the elasticity in tension $\left(E_{t, 0}\right)$ and tensile strength $\left(\sigma_{t}\right)$ of the SG 18 specimens were higher than those of the SG 15 specimens, and consistent with the strength difference obtained through bending tests. It could be confirmed that the difference of bending strength between SG 15 and SG 18 specimens was mainly caused by the tensile properties of the outer
Table 8 Tensile properties of outer laminate on tensile side

\begin{tabular}{llllll}
\hline Specimen & $\begin{array}{l}\boldsymbol{P}_{\max } \\
{[\mathbf{k N ]}]}\end{array}$ & $\begin{array}{l}E_{t, 0} \\
{\left[\mathbf{k N} / \mathbf{m m}^{2}\right]}\end{array}$ & $\begin{array}{l}\sigma_{t} \\
{\left[\mathbf{N} / \mathbf{m m}^{2}\right]}\end{array}$ & SD & $\begin{array}{l}\boldsymbol{\sigma}_{t}(\mathrm{TL5} \%) \\
{\left[\mathbf{N} / \mathbf{m m}^{2}\right]}\end{array}$ \\
\hline SG 15 & 4.38 & 7.85 & 58.02 & 7.39 & 43.74 \\
SG 18 & 5.25 & 9.48 & 69.96 & 8.53 & 53.47 \\
HG 15 & 9.11 & 11.61 & 121.68 & 20.27 & 82.53 \\
HG 18 & 9.68 & 11.98 & 125.50 & 16.03 & 94.54 \\
\hline
\end{tabular}

laminate. The tensile property of the HG 15 and HG 18 specimens was similar, also be consistent with the difference in bending strength.

\section{Reduction of bending strength of columns with interior notches}

To distinguish the influence of interior notches, the bending strength $F_{b}$ obtained from the condition with a notch (Test 1 ) was marked as $F_{\mathrm{b}-\mathrm{M}}$, and $F_{\mathrm{b}}$ obtained from the condition without notches (Test 2) was marked as $F_{\mathrm{b}-0}$. Figure 11 shows the cumulative distributions of the ratio of the bending strength with and without notches for each specimen. Coefficient $\beta$ is defined as the ratio between bending strength of columns with and without interior notches, as expressed in Eq. (5):

$$
\beta=\frac{f_{\mathrm{b}-\mathrm{M}}}{f_{\mathrm{b}-0}} .
$$

In Eq. (5), $f_{\mathrm{b}-0}$ is the referenced bending strength obtained from the mean value of each of the 30 specimens of Test 2 without notches; $f_{\mathrm{b}-\mathrm{M}}$ is the mean value of bending strength of each of the 10 specimens with different interior notches, determined through Test 1.

$\beta$ can also be regarded as the ratio of the effective section modulus $\left(Z_{\mathrm{e}}\right)$ to the nominal section modulus $\left(Z_{0}\right)$, which reflects the effects of stress concentration at the sharp interior corner of the notch on the reduction of allowable bending strength. However, the obtained values 


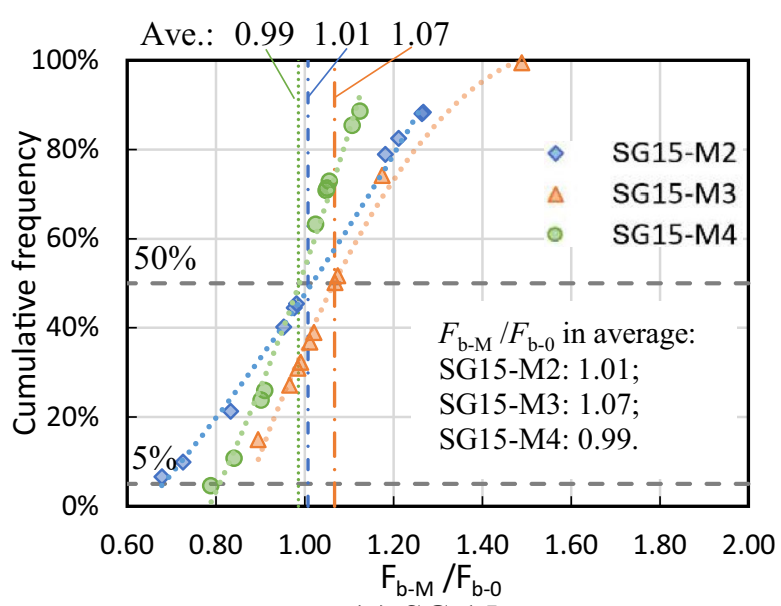

(a) SG-15

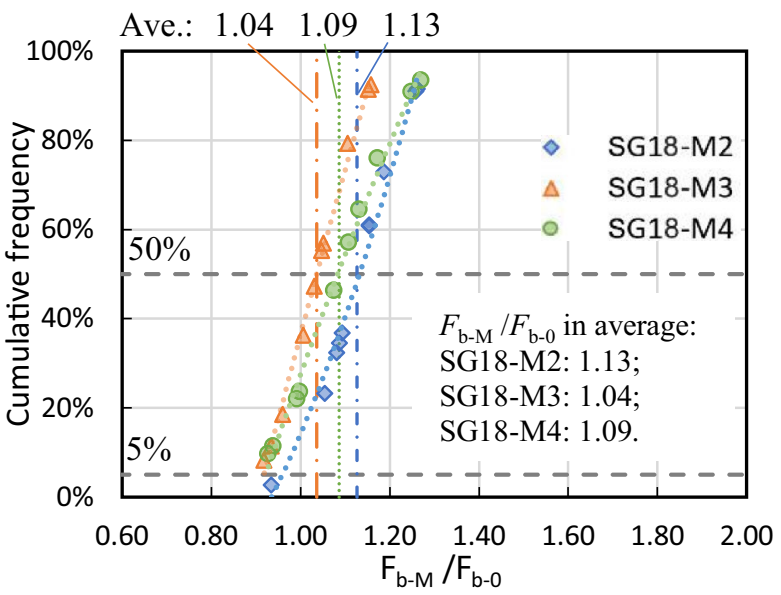

(c) $\mathrm{SG}-18$

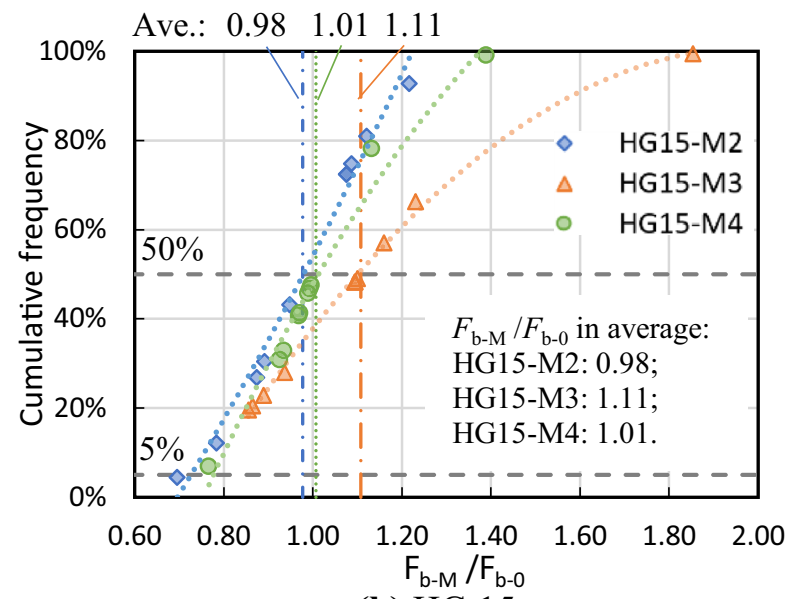

(b) $\mathrm{HG}-15$

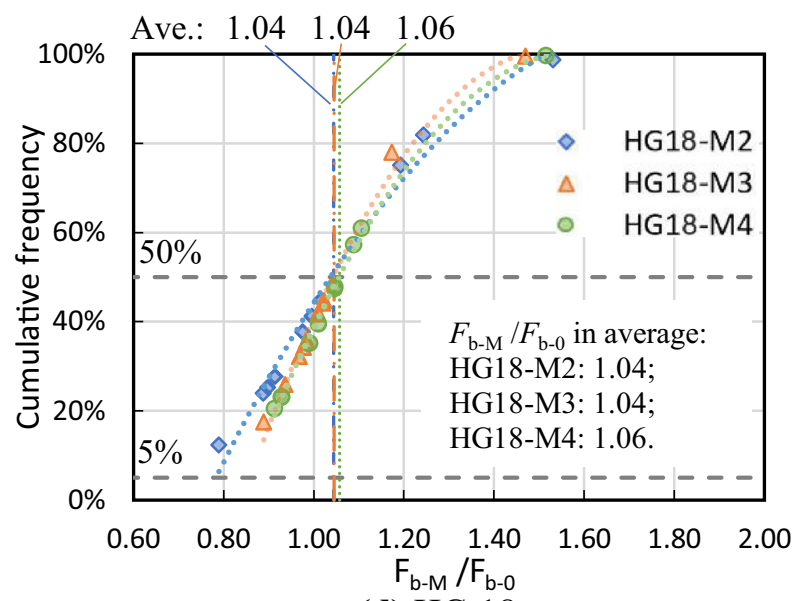

(d) $\mathrm{HG}-18$

Fig. 11 Ratio between $F_{\mathrm{b}-\mathrm{M}}$ and $F_{\mathrm{b}-0}$ of each specimen with and without notches

of $\beta$ were approximately 1.0 in both Japanese cypress and cedar specimens with three different notch types (Table 9), which were significantly higher than the regulations in AIJ standard for the reduction factor of a tension-side notched beam ( $\beta=0.45-0.6)$ [2] due to stress concentration. It is noteworthy that for a notch that normally penetrates through the beam in the width direction $[2,11-13]$, the strength reduction caused by both the section reduction and stress concentration is highly correlated to the notch depth. When considering the notch types for the traditional tenon-mortise joints on the columns, the notch width is only approximately $1 / 3$ of the column width. Based on the experimental statistics of the column specimens with two section sizes and three different notch types, it can be inferred that the continuous timber on both sides of the notch has a beneficial effect on maintaining a higher strength of the tensile side under bending and reducing the stress intensity at the notch corner. Even when the notch depth to column depth ratio reaches $1 / 3$, and the width loss ratio on tensile side of the

Table 9 Values of coefficient $\beta$ of specimens with different notch types

\begin{tabular}{|c|c|c|c|c|c|c|c|c|c|c|c|}
\hline \multicolumn{3}{|c|}{ SG15 } & \multicolumn{3}{|c|}{ HG15 } & \multicolumn{3}{|c|}{ SG18 } & \multicolumn{3}{|c|}{ HG18 } \\
\hline M2 & M3 & M4 & M2 & M3 & M4 & M2 & M3 & M4 & M2 & M3 & M4 \\
\hline 1.03 & 0.96 & 1.05 & 1.04 & 1.02 & 0.98 & 1.13 & 1.05 & 1.06 & 0.99 & 1.05 & 1.05 \\
\hline
\end{tabular}


column reaches 0.4 (SG15 and HG 15 specimens), there is no additional reduction in the bending strength, but the standard deviation of the test data tends to increase. Hence, in addition to the notch depth, the width loss ratio on the tensile side should also be regarded as a nonnegligible factor in evaluating the reduction of flexural properties of columns with interior notches in traditional timber frames.

\section{Conclusions}

Columns with interior notches in traditional Japanese timber frames were selected as research object in this study. The difference in the bending strengths of columns under $3 \mathrm{P}$ and $4 \mathrm{P}$ load configurations was investigated, and the load-bearing capacities of columns with different types of interior notches were evaluated through experimental tests and statistical analyses. The following conclusions were drawn:

(1) The mean bending strengths obtained through 3P bending tests on the columns made of Japanese cedar and Japanese cypress were higher than those obtained through 4P bending tests, with an average increase rate of 1.14 for different section sizes. However, the difference in TL5\% of the bending strength between these two load configurations decreased significantly owing to the higher standard deviation of the experimental data under 3P bending.

(2) Although the mean values of bending strengths of the specimens with three different types of notches were consistent with those without notches, the standard deviations of the load-bearing capacity were higher in specimens with a higher percentage of width loss ratio on the tensile side. Combined with the failure phenomenon, the fracture position showed higher correlations with the boundary of the shallow but wider notch on the tensile side. The effects of the transverse opening and notch on the bending strength were insignificant.

(3) The obtained coefficient $\beta$ reflecting the effects of stress concentration at the notch was approximately 1.0 in both Japanese cypress and cedar specimens with three different notch types. It can be inferred that the continuous timber on both sides of the notch has a beneficial effect on maintaining a higher strength and reducing the stress intensity around the notch.

\section{Acknowledgements}

This study is one of the items of the project for the promotion and maintenance for building standards by MLIT. The first author would also like to acknowledge the China Scholarship Council (CSC) for its financial support (No. 201908050049).

\section{Authors' contributions}

ZL performed the bending tests and analysis of columns with interior notches and was a major contributor in writing the manuscript. HI supervised the project and planned the experiments. AK performed the comparative bending tests of $3 \mathrm{P}$ and $4 \mathrm{P}$ load configurations. TN contributed to the improvement of statistical analysis. YA and NK aided in the verification of the result and worked on the manuscript. All authors provided critical feedback and helped shape the research, analysis and manuscript. All authors read and approved the final manuscript.

\section{Funding}

This study is a part the project for the promotion and maintenance for building standards by Ministry of Land, Infrastructure, Transport and Tourism, Japan; China Scholarship Council, 201908050049.

\section{Availability of data and materials}

The datasets used and analyzed in the current study are available from the corresponding author on reasonable request.

\section{Declarations}

\section{Competing interests}

The authors declare that they have no competing interests.

\section{Author details}

${ }^{1}$ Research Institute for Sustainable Humanosphere, Kyoto University, Kyoto, Japan. ${ }^{2}$ Faculty of Engineering, Osaka Sangyo University, Daito, Japan.

${ }^{3}$ National Institute for Land and Infrastructure Management, Tsukuba, Japan.

${ }^{4}$ School of Architecture, Kogakuin University, Shinjuku City, Japan.

Received: 30 March 2021 Accepted: 26 November 2021

Published online: 20 December 2021

\section{References}

1. Li Z, Isoda H, Kitamori A, Nakagawa T, Araki Y, Que Z (2021) Lateral resistance mechanism of a frame with deep beams and hanging mud walls in traditional Japanese residential houses. Eng Struct 244:112744. https:// doi.org/10.1016/j.engstruct.2021.112744

2. Architectural Institute of Japan (2006) AlJ standard for structural design of timber structures. Maruzen publishing Inc, Tokyo, pp 188-193 (in Japanese). ISBN978-4-8189-0569-6

3. ISO 13910-2014 (2014) Timber structures-Strength graded timber-Test methods for structural properties. International Organization for Standardization, Switzerland, pp 4-5

4. HOWTEC (2011) Structural timber strength test manual. Japan Housing and Wood Technology Center, Tokyo, pp 7-10 (in Japanese)

5. Thelandersson S, Larsen HJ (eds) (2003) Timber engineering. Wiley, Hoboken, pp 56-58

6. Yoshihara H, Kubojima Y, Ishimoto $T$ (2003) Several examinations on the static bending test methods of wood using Todomatsu (Japanese fir). For Prod J 53:39-44

7. Hein PRG, Brancheriau L (2018) Comparison between three-point and four-point flexural tests to determine wood strength of eucalyptus specimens. Maderas Ciencia y tecnologia 20(3):333-342. https://doi.org/ 10.4067/S0718-221X2018005003401

8. ANSI/NDS-2015 (2015) National Design Specification for Wood Construction (2015 edition). American wood council, pp 15, 32

9. BS 5268-2:2002 (2002) Structural use of timber-Part 2: code of practice for permissible stress design, materials and workmanship. Standard policy and strategy committee; B.C., pp 15, 37

10. Ashby MF, Easterling KE, Harrysson R (1985) The fracture and toughness of woods. Proc R Soc A Math Phys Eng Sci A398:261-280. https://doi.org/ 10.1098/rspa.1985.0034 
11. Murphy JF (1986) Strength and stiffness reduction of large notched beams. J Struct Eng 112(9):1989-2000. https://doi.org/10.1061/(ASCE) 0733-9445(1986)112:9(1989)

12. Murphy JF (1979) Using fracture mechanics to predict failure of notched wood beams. In: First International Conf. on Wood Fractures, Vancouver, B.C., pp 159-173

13. Forest Products Laboratory (2010) Wood handbook-wood as an engineering material (Centennial edition). United States. Dept. of Agriculture (USA)

14. Shojo N, Hayasaki Y, Ohashi Y (2009) Study of flexural performance of wooden members with the partial loss of section area. J Struct Constr Eng AlJ 74(635):97-103. https://doi.org/10.3130/aijs.74.97 (in Japanese)

15. Notification No.1920 (2013) Japanese Agricultural Standard for Sawing Lumber, Ministry of Agriculture, Forestry and Fisheries of Japan (in Japanese)

16. Notification No.1152 (2007) Japanese Agricultural Standard for Glued Laminated Timber, Ministry of Agriculture, Forestry and Fisheries of Japan (in Japanese)

17. JIS Z 2101 (2009) Methods of test for woods. Japanese Standard Association, Japan Wood Research Society (in Japanese)

18. Kolmann F, Cote WA (1984) Principles of wood science and technology, Part I. Solid wood. Solid wood, Berlin, p 302

19. Divós F, Tanaka T (2005) Relation between static and dynamic modulus of elasticity of wood. Acta Silvatica \& Lignaria Hungarica 1:105-110

\section{Publisher's Note}

Springer Nature remains neutral with regard to jurisdictional claims in published maps and institutional affiliations.

\section{Submit your manuscript to a SpringerOpen ${ }^{\circ}$ journal and benefit from:}

- Convenient online submission

- Rigorous peer review

- Open access: articles freely available online

- High visibility within the field

- Retaining the copyright to your article

Submit your next manuscript at $\boldsymbol{\nabla}$ springeropen.com 